\title{
The Relation between the Budget Deficit and Energy Demand in the Selected European Countries and Turkey: Panel Cointegration Analysis
}

\author{
Zerife Yildirim and Ayşe Atilgan Yaşa
}

\begin{abstract}
Within a country in the current globalized world, there is being an immense increase in energy demand due to a rapidly growing economy, changing living standards, population growth and rapid urbanization. Although the subject of some noteworthy studies has been on the energy policies, there are not so many of them focused on the correlation between energy demand and the budget deficit. Considering the researches ever made, mostly for developing countries, it is derived that the level of energy demand exceeds the level of energy supply.

In the countries where there exists limited energy production capacity as well as, adversely, a huge growth of energy demand, that has resulted in dependency on high-cost energy resources or energy imports. However, these countries are diversified from each other with varying degrees of budget balances, supply-demand relations, or underground energy base. In this study, we aim to focus on the relationship between budget deficit and energy demand in some European countries and Turkey within the years of 1960-2013. In order to determine that relationship, panel causality test, panel unit root tests, and panel cointegration analysis are used in terms of methodological framework.
\end{abstract}

Index Terms-Budget deficit, energy demand, European countries, panel unit root test, panel ARDL cointegration, panel causality.

\section{INTRODUCTION}

Over the last decades, one of the essential problems within the countries that causes political difficulties, or even the wars, is energy resources issue. The energy resources are dispersed differently across every country, and the constraint of the resources has resulted in dependency on energy imports for one. The increase in energy demand reduces the existing energy reserves so that it elicits a world competition for energy resources in financial terms. Hence, a huge level of investment is required in order to meet the growth in energy demand.

In which country the public revenue is not sufficient for supplying to finance the investments, that country encounters with the deficiency in its budget. The debate on the usage of the budget deficit has mainly emerged to investigate whether it has targeted its aim or not. The reason behind that debate is that the budget deficit makes a positive impact on a determined variable whereas it makes the other way around for another one.

Mostly in the countries dependent on the energy supplied

Manuscript received March 30, 2014; revised August 20, 2014.

Zerife Yildirim and Ayşe Atilgan Yaşa are with the Dokuz Eylül University, Turkey (e-mail: \{zerifeyildirim, a_atilgan45\}@hotmail.com). by the other countries, there has been a positive correlation between the energy imports and the current account deficit. To be more specific, growing energy demand of developing countries has resulted in depletion of energy resources as well as increase in energy imports so that there emerges current account deficits.

It is theoretically obvious that there is a relationship between the account deficit and energy demand. This study is intended to determine whether the energy imports influence the budget planning of a country and how it actualizes itself. In this study, the data, that estimates the correlation between the budgetary equilibrium and energy demand belonging to the years between 1990 and 2012 in Germany, France, Italy, Spain and Turkey that are countries particularly selected for the study, is used. Additionally, panel ARDL (autoregressive distributed lag) cointegration and causality tests are applied to analyze the improved data and the parameters.

\section{The Energy Resources And Budget Deficit of Some EUROPEAN COUNTRIES}

\section{A. Energy Resources}

Germany, which is the largest energy consumer of Europe, is heavily dependent on external energy resources. By 2013, the energy resources of Germany are listed as; oil (37\%), coal $(24 \%)$, natural gas $(22.8 \%)$, nuclear $(12.2 \%)$, hydro and wind $(1 \%)$, and others (3\%) [1].

Germany ranks fifth in the world in terms of fuel consumption. It imports the fuel mostly from Russia, Norway and United Kingdom. Germany is a regional as well as world leader on several categories of renewable energy use. In 2013, Germany was the largest European producer of non-hydro renewable electricity by utilizing its huge solar and wind energy sources [2]. In the long term plans, the German government aims to increase the share of the renewable energy, and to prevent from including nuclear energy in its energy mix [3].

France has the second-largest economy in Europe in terms of Nominal Gross Domestic Product (GDP), just after Germany, and it ranks the fifth in the world. Due to the scarcity of domestic energy production, the country relies on energy imports to meet most of its oil and gas demand. France was the 12th largest oil consumer and 7th largest net importer of petroleum liquids in 2011[4].

Since the oil crisis of 1970 , France has begun a policy to decrease its energy dependency. What the most consumed energy sources in France are listed as electricity and natural gas. Nuclear energy plays a crucial role in France for the 
energy production, and $80 \%$ of its electricity need is produced with the help of nuclear technologies. The consumed energy mix of France is headlined as: oil $(33,30 \%)$, electricity $(42,50 \%)$, natural gas $(14,80 \%)$, coal $(4,90 \%)$, renewable energy $(4,50 \%)$. As stated before, France is the 12th largest oil consumer, and it meets its energy demand by importing mostly from Russia, Norway and United Kingdom. When it comes to the natural gas sources of France, it imports from Algeria, Nigeria, Qatar and Egypt. On the other hand, France is the 3rd electricity exporter behind Canada and Germany.

Spain is not very rich in terms of domestic energy resources when excluding its coal reserves. Growing demand is driven by rapid industrial growth which in emerging markets calls for a rise in the supply capacity. However, the absence of sufficient oil reserves, hydro energy capacity, and dwindling the supply of easily accessible high-quality coal reserves problematizes the energy issue for the country more. Until early 1980s, Spain has been increasingly getting dependent on external fuel energy, and at the same time, the total energy consumption was rising within the years of 1973-79 [5]. Due to the adjustment to slow the rate of economic growth and changing qualifications of energy market in 1970s, Spanish's energy consumption has declined by early 1980 s.

The National Energy Plan (Plan Energetico Nacional--PEN), an official energy policy, was firstly introduced in 1978. After a revision of the plan in 1983, as to cover the 1984-93 period, the new-PEN had aimed to rationalize the energy consumption and to decrease the dependency of Spain on energy imports. In addition, it has insisted on the reorganization of the oil industry as well as establishing a financial reorganization of the electricity industry. In contrast to the $1978-87$ plan, it has reduced the role of nuclear energy in its energy mix [6].

Spain might be still spanning its industrial age in terms of energy resources. Spain mainly uses fossil fuels like crude oil, petroleum products, and natural gas whereas the usage of nuclear energy is increasing in the country [7]. However, there are also some signs of progress in Spain regarding rising use of the renewable resources such as hydro power.

Italy, as a country relying on external energy sources, imports oil and natural gas in particular. It meets its need of crude oil from Libyan, Azerbaijan, Saudi Arabia and Russia. Italy has the second largest crude oil refining plants within the European countries after Germany. Most of the electricity consumption is met by the imports from France. The share of primary energy dedicated to the electricity production is above $35 \%$, and it has been steadily increasing since 1970 s [8]. Electricity is produced mainly from natural gas, which accounts for the source of more than half of the total final electric energy produced. Another important source is hydroelectric power, which was practically the only source of electricity until 1960. Wind and solar power are growing rapidly in the recent years owing to the high incentives.

Turkey is one of the fastest growing energy markets in the world, and it has been experiencing a rapid energy demand growth. Turkey plays a crucial role as a reliable transit country, as well. The limits of the domestic energy sources and technologies to drill oil in light of a rapid energy demand growth have resulted in energy imports, primarily of oil and gas [9]. Furthermore, it is geographically located in close proximity to East-West and North-South energy axis, and it establishes one of the energy transit flows for the consumer countries. In the long term, Turkey aims to realize its own energy security by reducing the dependency on energy imports. The intentions are to utilize its indigenous hard coal reserves, hydro and renewable resources such as wind and solar energy as well asto include the nuclear energy in its energy mix without ignoring the target of increasing renewables. By 2023, Turkey, as a country having a substantial potential for renewable energy in terms of hyrdro, solar, wind and geothermal, proposes producing $30 \%$ of its electricity need from the renewable energy [10].

An economic growth in a country triggers an increase in energy demand [11], and that builds energy economies of the world. As there occurs an upward in energy demand, it is firstly met by harnessing from the primary energy supplies. The primary energy consumptions of the European countries are listed as below [12]:

TABLE I: THE PRIMARY ENERGY CONSUMPTION OF EUROPEAN COUNTRIES

\begin{tabular}{lccc|ccc}
\hline \hline & \multicolumn{7}{c}{ Million TEP } \\
\hline Countries & $\mathbf{2 0 0 8}$ & $\mathbf{2 0 0 9}$ & $\mathbf{2 0 1 0}$ & $\mathbf{2 0 1 1}$ & $\begin{array}{c}\text { The propotions around } \\
\text { the world (\%) 2010 }\end{array}$ & Rank \\
Germany & 326,8 & 307,4 & 319,5 & 306.4 & 2,7 & 6 \\
France & 257,8 & 244,0 & 252,4 & 242.9 & 2,1 & 10 \\
Italy & 180,7 & 168,3 & 172,0 & 168.5 & 1,4 & 14 \\
Spain & 157,1 & 146,1 & 149,7 & 145.9 & 1,2 & 16 \\
Turkey & 103,8 & 101,0 & 110,9 & 118.8 & 0,9 & 21 \\
World Total & 11,536 & 11,363 & 12,002 & 12.274 & 100 & \\
\hline \hline
\end{tabular}

According to Table I, it is estimated that the consumption level of the energy sources and the increase in energy demand seen in both France and Germany might be associated to their development levels when comparing to other listed countries. In Italy, Spain and Turkey, applied anti-conjectural policies affect the supply-demand relations, and that causes to a stagnation of the supply-demand equilibrium and increases the dependency on external energy sources. Other common points of these countries are that they do not meet their energy demands towards their directed aims, and they do not 
use the production inputs in an appropriate way. That situation prevents these countries from owing a strong economy and, even worse, the alternatives to meet the energy demand such as privatization or loan cause backfires for the countries.

The production-consumption indicators of the countries mentioned in this study in terms of the energy sources are listed as below [13]:

TABLE II: THE PRODUCTION-CONSUMPTION INDICATORS OF COUNTRIES

\begin{tabular}{|c|c|c|c|c|c|}
\hline $\begin{array}{l}\text { Countries / } \\
\text { proportion over } \\
\text { the world \%) }\end{array}$ & Germany & France & Italy & Spain & Turkey \\
\hline $\begin{array}{l}\text { Electricity } \\
\text { production }\end{array}$ & 2,9 & 2,7 & 1,4 & 1,4 & 1,0 \\
\hline $\begin{array}{l}\text { Natural gas } \\
\text { consumption }\end{array}$ & 2,6 & 1,5 & 2,4 & 1,1 & 1,2 \\
\hline $\begin{array}{lr}\text { Natural } & \text { gas } \\
\text { imported } & \text { from } \\
\text { Russia } & \end{array}$ & 17,23 & 4,03 & 7,11 & - & 8,33 \\
\hline $\begin{array}{l}\text { Hydro- electricity } \\
\text { consumption }\end{array}$ & - & 0,02 & 0,01 & 0,01 & 0,02 \\
\hline $\begin{array}{l}\text { Capacity of } \\
\text { geothermal } \\
\text { energy }\end{array}$ & 0,1 & 0,1 & 7,9 & - & 0,7 \\
\hline $\begin{array}{l}\text { Capacity of solar } \\
\text { energy }\end{array}$ & 43,5 & 2,6 & 8,8 & 9,8 & 0,0 \\
\hline $\begin{array}{l}\text { Capacity of wind } \\
\text { energy }\end{array}$ & 13,7 & 3,0 & 2,9 & 10,2 & 0,8 \\
\hline $\begin{array}{l}\text { Coal } \\
\text { consumption }\end{array}$ & 2,2 & - & - & - & 1,0 \\
\hline
\end{tabular}

With regard to Table II, we demonstrate that Germany has the highest proportion with its level of production and consumption of energy resources without regarding the capacity of geothermal energy within those countries. This indicator implies that developed countries have more capacity of sources than developing countries. Moreover, Spain shows up as a single country with its none of imported natural gas from Russia whereas the other countries all import.

\section{B. Budget Deficits}

In basic financial terms, a budget deficit is defined when the government expenditures exceed the government revenues. It is sum of the net investment income, account transfers (trade incomes, interest rate, and rent), and the difference of the imported and exported purchases of goods and services [14]. Budget balance is defined as the equation of the government's proposed revenues and expenditures for a financial year. Current account deficit means that the net investment income and balance of trade are avoidant whereas the budget deficit means that government's proposed spending exceeds the government revenues. A macroeconomic theory called as twin deficits anomaly points the existence of a strong dual link between these deficits.

For the countries mentioned in our study, a rapid energy demand growth becomes a problem due to their dependency on external energy sources as well as their inability to produce alternative energy sources such as renewable energy to increase the domestic energy supplies. The most significant outcome of getting dependent on energy imports reveals huge current account deficits. In particular, as the oil prices increase, the governments usually use public funding as a policy, and that causes not only to deferring to search for the alternative energy sources but also to triggering financial problems for years [15].

The analysis of the graph [16] below Fig. 1 on the relationship between the energy demand and budget deficit of the countries might be considered as the primary motive of our study:

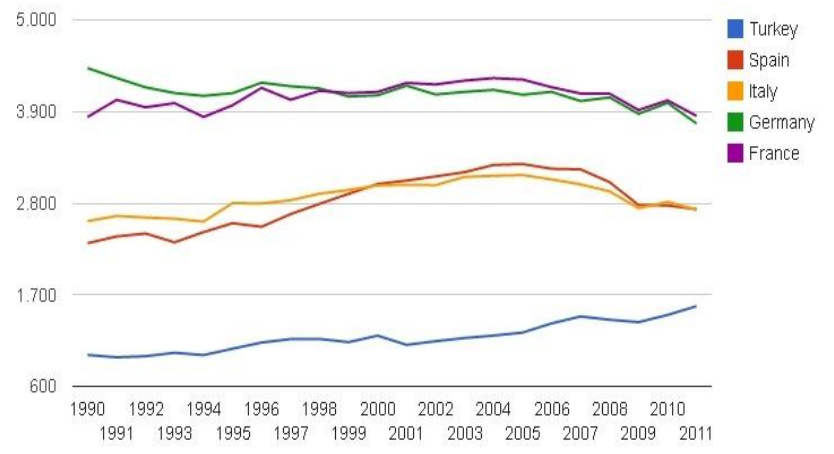

Fig. 1. Energy use per capita (measure: kilogram of oil equivalent.

One of the indications of a country's development and industrialization level is in how much energy is used. Turkey ranks the $65^{\text {th }}$ in the world with its $1.551 \mathrm{~kg}$ of oil per capita consumption of energy, and it is within the last ranks within European countries. Within the selected countries, Germany with 4,027 kg use of oil consumption per capita and France with $4,258 \mathrm{~kg}$ become Europe's largest energy consumers. Spain with 3,208 $\mathrm{kg}$ of oil consumption per capita and Italy with $3,001 \mathrm{~kg}$ are very close countries in terms of energy consumption per capita.

In order to analyze the relation between the energy demands and budget deficits for the selected countries, the required information is given via Fig. 2 by showing the government budget balance as percent of GDP.

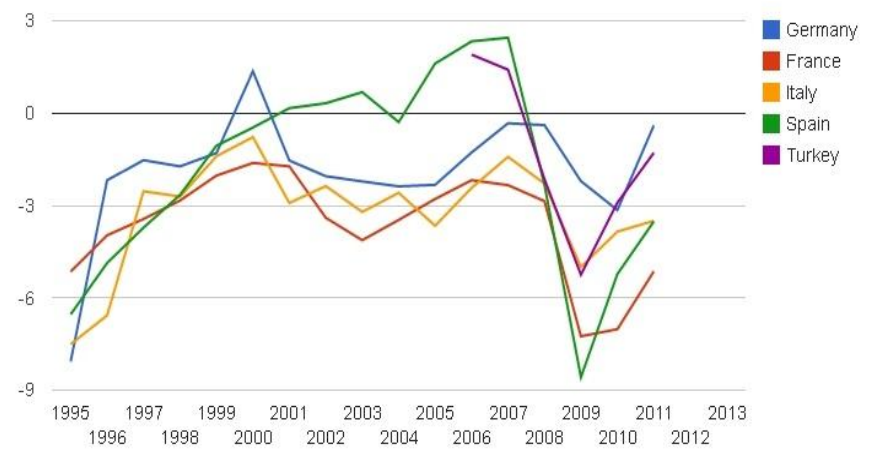

Fig. 2. Government budget balance as percent of GDP (measure: percent).

In terms of the adjustment of the budget balances to GDP, by 2011, Germany and Turkey have approximately balanced inflows and outflows as referring budget balance in their budget plannings. Due to the crisis of 2007 emerged in USA, there has been a huge crisis in financial markets of Italy and Spain, having started from the second half of 2008. The budget balances of some European countries such as 
Portugal, Greece, Spain and Italy have been also affected from that crisis in a negative manner [17]. For France, economy of the country has recorded a lower growth rate that was even under the rates of the developed countries ever since 1990s [18]. Within 1990 and 2000, the growth rate of France was measured as over the \%2.2 annual increase [19], however it has decreased under that rate after 2000.

In today's world, the development level of the countries is measured according to their amounts of energy production and consumption. In this sense, an economic growth might be associated with how much the country is dependent on energy imports and how much it realizes its own energy security.

The analysis of the graph is below Fig. 3 which is about the energy production of the countries.

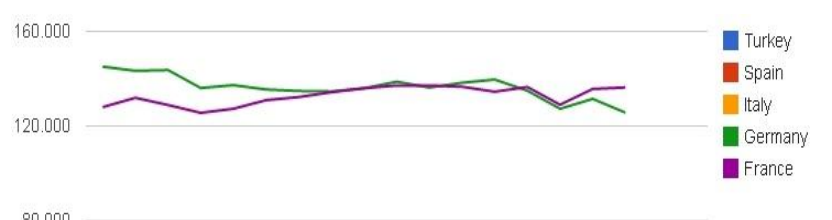

80.000

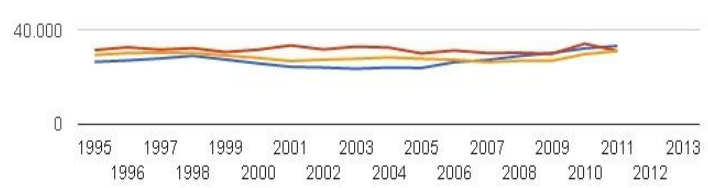

Fig. 3. Energy production ( measure: kilograms of oil equivalent).

According to Fig. 3, by 2011, the annual energy generation of France is 136,074.3 kg of oil equivalent, as that value places it in the first rank, and Germany follows France with $124,194.1 \mathrm{~kg}$ of oil equivalent. In the $3^{\text {rd }}$ rank, Turkey's energy generation is $32,064.2 \mathrm{~kg}$ of oil equivalent. The amounts of Spain and Italy are ranked in order as $31,778.0 \mathrm{~kg}$ and $31,556.2 \mathrm{~kg}$ of oil equivalent.

Net energy imports are estimated as energy use less production, both measured in oil equivalents. A negative value indicates that the country is a net exporter. Energy use refers to use of primary energy before transformation to other end-use fuels, which is equal to indigenous production plus imports and stock changes, minus exports and fuels supplied to ships and aircraft engaged in international transport.

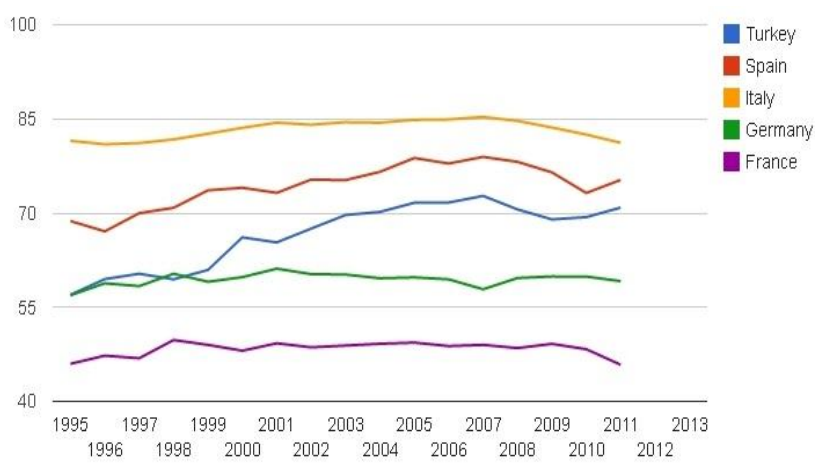

Fig. 4. Energy imports as percent of total energy use (measure: percent).

As regards Fig. 4, France imports $\% 46$ of its energy need as the least dependent country on energy imports. Germany follows France as importing \%60 of its energy need. Following, Turkey comes with $\% 71$, Spain with $\% 75$ and
Italy with $\% 81$.

Considering all these data, Turkey might be exemplified to reveal the relationship between the energy demand and the budget deficit. In Turkey, around $72 \%$ of the total energy demand is being met by the external energy resources [20]. The dependency on energy imports has resulted in an impact on not only budget deficit but also on the rate of economic growth. Turkey is one of the net energy importers and, there is a positive correlation between the energy imports and the budget deficit. Due to increase of input cost, the outputs of the country lose its competitive advantage within the other countries [21]. The primary reason for not considering a direct association between energy demand and the budget deficit, as shown in Turkey, is that many developing countries choose the privatization as a solution instead of establishing public investments. Need to emphasize that, the resultant of energy imports is directly seen in the account deficit more than in the budget deficit; but, the effect of the energy imports on general equilibrium of economy might result in the budget deficits.

\section{LITERATURE REVIEW}

The relationship between the energy demand and budget deficit is very substantial in theoretical, empirical and political manner. Although, it is not a very studied subject, there are some significant scholars' articles providing data on that issue. In the article of Demir (2013), the author aims to analyze the size and power of the interactions among the variables such as industrial production, account deficit and energy imports with the help of the use of vector autoregression model (VAR) including the cointegration, error correction model and Granger causality test. Considering the determinations of him, unidirectional casual relationship of Turkey appropriately is being rationalized from industrial production index and energy imports towards the account deficit.

Bilginoğlu ve Dumrul [22] (2012) demonstrate Turkey’s dependency on energy imports in the light of the JohansenJuselius procedure of cointegration analysis. Based on the analyses, the dependency on energy imports is positively related with the energy density, the gross national product and the energy consumptions of the residences.

The relationship between government revenues and expenditures is an issue that has been examined for several countries though an agreement is yet to be reached. Chang and Chiang (2009) investigate the relationship between government revenue and government expenditure in 40 Asian countries and indicate that there is a bidirectional causal relationship between government expenditures and revenues in both the long and the short run so that fiscal synchronization hypothesis is confirmed.

In the article of Ulusoy (2006), he intends to estimate the interactions between the energy demand and economic growth with the help of Granger causality test. In order to determine that interaction, the relationship between the sectoral consumption of oil, electricity and natural gas and the rate of economic growth is considered. According to the author, the resource of the energy is not directly affective to the economic growth whereas the increase on the proportion 
of energy resource inside national income makes a significant effect on economic growth rate. Moreover, it is emphasized in the study that the economic growth increases the energy consumption.

The study on the impact of the budget deficit upon the basic macroeconomic variables was made in accordance with VAR by Barışık and Kesikoğlu [23] (2003). The model compromised of variables like the budget deficit, inflation rate, account deficit, employment, growth rate and investment is estimated for 1987: 1-2003:4 periods. A relation between the budget deficit and inflation, account deficit and growth rate is determined.

In the article of Blackburne III and Frank (2007), they claim that the relation between the economic growth and the import rate might be determined by implementing panel cointegration test and panel causality test. In their study on the estimation of nonstationary heterogeneous panels, they use Panel Auto Regressive Distributed Lag (ARDL) method in order to estimate income per capita and inflation data in 24 countries. As the result of the model, the relationship between the parameters is not found as cointegrated.

Sandicilar (2012) aims to analyze the relationship between the economic growth and import data for BRIC (Brasil, Russia, India and China) countries. In the study, panel unit root, panel cointegration and panel causality tests are applied. According to the improved analysis in the short-run and long-run causality tests, the relationship stems from import data towards the economic growth.

Çınar (2011) uses the panel data analysis, panel unit root tests, cointegration test and long-term parameters to determine the relationship between the amount of $\mathrm{CO} 2$ emission per capita and GDP. A cointegrated relation between the amounts of $\mathrm{CO} 2$ emission and GDP is determined at the end of the analysis. Hence, an increase in GDP results in increasing level of pollution, and after a while, that increase in the pollution level proceeds.

Çinar (2010) has tested the panel data analysis of GDP within 1960-2008 in 27 OECD countries one by one. The stationary of data is examined by applying Levin-Lin Chu (LLC), Im-Pesaran and Shin (IPS) tests as well as a number of panel unit root tests such as Fisher ADF and Fisher PP. At the end, he claims that it is almost impossible to mention about the same stationary level for every country, and each country's might be identical.

\section{ECONOMETRIC ANALYSIS}

\section{A. Methodology and Data Set}

Panel data is defined as multi-dimensional data compromised of observations of multiple phenomena obtained over multiple time periods for the same firms or individuals. Time series data refers to a sequence of data points of economic variables measured in time spaces whereas cross-sectional data refers to data collected at the same point of time [24]. A panel has the basic form as stated below:

$$
y_{i t}=\alpha+X_{i t}^{\prime}+u_{i t} \quad i=1, \ldots . ., N \quad t=1, \ldots \ldots, T
$$

In the function, $i=1, . ., N$ is the individual dimension where the countries, firms or individuals are named whereas $t=1$,. $T$; is the time dimension. However, in the panel data analysis, the existence of unit roots should be checked likewise it is done in time series analysis. Because, the general panel data regression model is not reliable, and different unreliable assumptions on the precise structure of this general model can be made [25].

Before deterministic components of unit root tests, the dependence of cross-sectional must be checked inside the estimations of panel data analysis. In case it is not an issue, then the applicable tests are appealed [26]. In that study, the estimators named as $1^{\text {st }}$ generation unit root use Levin-Liu Chu (LLC) and Im-Pesaran and Shin (IPS) unit root tests. Although Individual unit root tests have limited power, the power of a test comes from the possibility of rejecting the null when it is false and the null hypothesis is unit root. In these tests, if the possibility is close to 0 , it means that each time series is stationary whereas if the possibility is close to 1 , it refers to that each time series contains a unit root Applied all tests aggregate the results of unit root tests for each panel variable, and give the estimations as one test. According to the estimations of the tests and critical values, the decision is made on an hypothesis and the series are set as stationary [27].

The cointegration analysis is applied in accordance with the improved estimations for the data excluded from the unit roots. Recently, one of the most common methods, Pesaran (2004), is a cointegration analysis used when the intersections of the series are heterogeneous. In this analysis, with the increase in time, observations inherent in large $N$, large $T$ dynamic panels, nonstationarity is also a concern. Recent papers by Pesaran, Shin, and Smith (1997, 1999) offer two important new techniques to estimate nonstationary dynamic panels in which the parameters are heterogeneous across groups: the mean-group (MG) and pooled mean-group (PMG) estimators. The MG estimator (see Pesaran and Smith 1995) relies on estimating $N$ time-series regressions and averaging the coefficients, whereas the PMG estimator (see Pesaran, Shin, and Smith 1997, 1999) relies on a combination of pooling and averaging of coefficients. The MG estimates are the unweighted mean of the $N$ individual regression coefficients. The PMG model allows for heterogeneous short-run dynamics and common long-run elasticities. Often only the long-run parameters are of interest. The default results of the pmg option include the long-run parameter estimates and the averaged short-run parameter estimates (Blackburne III and Franke, 2007).

Assume an autoregressive distributive lag (ARDL) $\left(q, q_{1}, \ldots \ldots ., q_{k}\right)$ dynamic panel specification of the form

$$
y_{i t}=\sum_{j=1}^{P} \lambda_{i j} y_{i, t-j}+\sum_{j=0}^{q} \delta_{i j}^{\prime} X_{i, t-j}+\mu_{i}+\varepsilon_{i t}
$$

where the number of groups $i=1,2, \ldots . ., N$; the number of periods $t=1,2, \ldots \ldots, T ; X_{i t}$ ise a $k \times 1$ vector of explanatory variables; $\delta_{i t}$ are the $k \times 1$ coefficient vectors; $\lambda_{i j}$ are scalars; and $\mu_{i}$ is the group-specific effect. $T$ must be large enough such that the model can be fitted for each group separately. 
Time trends and other fixed regressors may be included.

If the variables in (1) are, for example, I(1) and cointegreted, then the error term is an $I(0)$ process for all i. a principal feature of cointegrated variables is their responsiveness to any deviation from long-run equilibrium. This feature refers to their responsiveness to any deviation from long-run equilibrium. This feature implies an error correction model in which the short-run Dynamics of the variables in the system are influenced by the deviation from equilibrium. Thus it is common to reparameterize (1) into the error correction equation [28].

$$
\Delta y_{i t}=\varphi_{i}\left(y_{i, t-1}-\varphi_{i}^{\prime} X_{i t}\right)+\sum_{j=1}^{p-1} \lambda_{i j}^{*} \Delta y_{i, t-1}+\sum_{j=0}^{q-1} \delta_{i j}^{*} \Delta X_{i, t-j}+\mu_{i}+\varepsilon_{i t}
$$

where

$$
\begin{array}{r}
\phi_{i}=-\left(1-\sum_{j=1}^{p} \lambda_{i j}\right), \theta_{i}=\sum_{j=0}^{q} \delta_{i j} /\left(1-\sum_{k} \lambda_{i k}\right), \lambda_{i j}^{*}= \\
\quad-\sum_{m=j+1}^{p} \lambda_{i m} \quad j=1,2, \ldots \ldots, p-1, \\
\text { and } \delta_{i j}^{*}=-\sum_{m=j+1}^{q} \delta_{i m} \quad j=1.2 \ldots \ldots, q-1 .
\end{array}
$$

The parameter $\phi_{i}$ is the error-correcting speed of adjustment term. If $\phi_{i}=0$, then there would be no evidence for a long-run relationship. This parameter is expected to be significantly negative under the prior assumption that the variables Show a return to a long-run equilibrium. Of particular importance is the vector $\phi_{i}^{\prime}$, which contains the long-run relationships between the variables.

More recently, Pesaran, Shin, and Smith (1997, 1999) have proposed a PMG estimator that combines both pooling and averaging. This intermediate estimator allows the intercept, short-run coeffcients, and error variances to differ across the groups (as would the MG estimator) but constrains the long-run coeffcients to be equal across groups (as would the FE estimator). Since (2) is nonlinear in the parameters, Pesaran, Shin, and Smith (1999) develop a maximum likelihood method to estimate the parameters. Expressing the likelihood as the product of each cross-section's likelihood and taking the log yields (Blackburne III and Franke, 2007).

$$
\begin{gathered}
I_{T}\left(\varphi^{\prime}, \phi^{\prime}, \sigma^{\prime}\right)=\frac{T}{2} \sum_{i=1}^{N} \ln \left(2 \pi \sigma_{i}^{2}\right)-\frac{1}{2} \sum_{i=1}^{N} \frac{1}{\sigma_{i}^{2}}\left\{\Delta y_{i}-\varphi_{i} \xi_{i}(\varphi)\right\} \\
i=1, \ldots \ldots \ldots \ldots, N, \quad \text { for } \quad \text { Where } \\
\xi_{i}(\phi)=y_{i, t-1}-X_{i} \phi_{i}, H_{i}=I_{T}-W_{i}\left(W_{i}^{\prime} W_{i}\right) W_{i}, I_{T}
\end{gathered}
$$

is an identity matrix of order $T$, and

$$
W_{i}=\left(\Delta y_{i, t-1,}, \ldots, \Delta y_{i, t-p+1} \Delta X_{i}, \Delta X_{i, t-1}, . ., \Delta X_{i, t-q+1}\right)
$$

\section{B. Empirical Data}

\section{1) Econometric application in the relationship between} the energy demand and budget deficit

In that article, the relationship between the energy demand and budget deficit belonging to the data of Turkey and some
European countries such as Germany, France, Italy, Spain

\begin{tabular}{|c|c|c|c|}
\hline & & $\mathrm{BD}$ & EI \\
\hline $\operatorname{LLC}_{\text {t-stat }}$ & $\begin{array}{l}\text { level } \\
1^{\text {st }} \text { difference }\end{array}$ & $-2.55177(0.005)^{*}$ & $\begin{array}{l}-1.62882(0.051) \\
-1.91462(0.027)^{*}\end{array}$ \\
\hline IPS $_{\mathrm{w} \text {-stat }}$ & $\begin{array}{l}\text { level } \\
1^{\text {st }} \text { difference }\end{array}$ & $-3.06186(0.001)^{*}$ & $\begin{array}{l}-0.57372(0.283) \\
-2.44399(0.007)^{*}\end{array}$ \\
\hline
\end{tabular}
has been intended to analyze.

In manner of the unit root tests, the estimators of Levin-Lin Chu (LLC), Im-Pesaran Shin as $1^{\text {st }}$ generation unit root test (IPS) are used to eliminate the confirmaations. LLC and IPS are developed in order by Levin vd. (2003) and Im vd.(2003). The results are shown as:

TABLE III: THE ESTIMATIONS OF PANEL UNIT ROOT TEST

As shown in Table III, in case one of the parameters in the panel data set is stationary on BD level, it has the feature of $\mathrm{I}(0)$ in the level and $\mathrm{I}(1)$ in the $1^{\text {st }}$ difference. Considering the estimations of the unit root test, the effects of the parameters on each other are identical. Based on that variance, panel ARDL is applied to estimate the long run relationships.

Panel ARDL is applied to interpret the long run

\begin{tabular}{|c|c|c|}
\hline & PMG & MG \\
\hline \multicolumn{3}{|c|}{ Long run coefficient } \\
\hline EI & $0.8956051(0.186)$ & $28.63702(0.058)^{* *}$ \\
\hline \multicolumn{3}{|c|}{ Standard error coefficients } \\
\hline Q & $0.6485934(0.000)^{*}$ & $0.6737693(0.000)^{*}$ \\
\hline \multicolumn{3}{|c|}{ Short run coefficients } \\
\hline EI & $-102.6363(0.311)$ & $-100.8476(0.325)$ \\
\hline \multicolumn{3}{|c|}{ Diagnostic tests } \\
\hline Log_likehood & -675.2707 & \\
\hline
\end{tabular}
coefficients. In the application, the estimators of PMGE (Pooled Mean Group Estimation) and MGE (Mean Group Estimation) developed by Pesaran vd. (2004) are tested. During the evaluation of the model, Hausman test helps one evaluate if the estimators of PMG or MG correspond to the data, and it checks the consistency of the estimators.

TABLE IV: ESTIMATIONS OF PMG AND MG TEST

In the light of Hausman test, we accept the null hypothesis and the estimators of both PMG and MG as consistent for the countries concerned in this study. According to Table IV, MG is the only efficient estimator. Even if the standard error calculations are statistically significant, the indication of them is positive. It implies that, in the long-term, the difference between the budget balance and energy imports increases, and there is not a cointegrated relationship between them, as well. In the short-term, it refers to the absence of a causal relationship between the parameters. $Q$ is a statistically significant coefficient, points out the deviation, and the absence of a long run relationship of the parameters in the budget balance function. It is determined by that coefficient that the variances in the budget balance are not out of the energy imports. Long run coefficient reached by Panel ARDL is found as statistically significant in MG.

During the evaluation of the model, the long run relationship of the budget balance function is modeled by the significant and efficient estimators in the panel data set. 
As given in Table III, in accordance with the parameters of budget balance (BD) and energy demand (EI) in LLC and IPS unit root tests, the results confirm that panel does not contain unit root, and is stationary in BD level as I (0). When it comes to the other parameter EI, the results confirm that it contains unit root as I (1), but it becomes stationary in the $1^{\text {st }}$ difference. In light of the estimations of panel ARDL cointegration test, although EI coefficient is significant, there does not occur a short run causal relationship owing to Granger causality test due to the fact that the standard error detection mechanism is not on. In the long run, there does not exist a balanced relation owing to the fact that the coefficient is not measured between 0 and -1 as well as the error variance of the parameters is not detected.

With the applications of unit root tests, the effects of the parameters' correlation appear separately, each is identical within itself, and due to that variance, panel ARDL is done. That results in the estimation that there is not a long run relationship between $\mathrm{BD}$ and EI. The Hausman test results are shown by Table V. The difference in these models is estimated by the familiar Hausman test. Considering the chi2 value as 3,31 ve prob as 0,069 in case of $\alpha=5 \%$, we conclude that PMG estimator, inconsistent estimator and MG model are preferred. When the chi2 as 3,31 and prob as 0,069 are shown up for the value of $\alpha$ of $10 \%$, we conclude that PMG estimator and the efficient estimator under null hypothesis are preferred to estimate. The causality test is applied to determine the side of the relation.

TABLE V: HAUSMAN TEST

\begin{tabular}{|c|c|c|c|}
\hline \multicolumn{4}{|c|}{---- Coefficients ---- } \\
\hline (b) & (B) & (b-B) & $\operatorname{sqrt}\left(\operatorname{diag}\left(\mathrm{V} \_\mathrm{b}-\mathrm{V} \_\mathrm{B}\right)\right)$ \\
\hline $\mathrm{mg}$ & pmg & Difference & S.E. \\
\hline$x \mid 28.63702$ & .8956051 & 27.74141 & 15.25633 \\
\hline
\end{tabular}

$\mathrm{b}=$ consistent under $\mathrm{Ho}$ and $\mathrm{Ha}$; obtained from xtpmg

$\mathrm{B}=$ inconsistent under Ha, efficient under Ho; obtained from xtpmg

Test: Ho: difference in coefficients not systematic

chi2 $(1)=3.31$

Prob $>$ chi $2=0.0690$

\section{TABLE VI: CAUSALITY TEST}

Pairwise Dumitrescu Hurlin Panel Causality Tests

Sample: 19902012

Lags: 2

\begin{tabular}{lccc} 
Null Hypothesis: & W-Stat. & Zbar-Stat. & Prob. \\
& & & \\
EI does not homogeneously cause BD & 2.72748 & 0.37427 & 0.7082 \\
BD does not homogeneously cause EI & 1.70473 & -0.49222 & 0.6226 \\
\hline
\end{tabular}

In Table VI, the causality of the relationship between budget balance and energy imports is analyzed by Pairwise Dumitrescu Hurlin Panel. Having determined the results of the table, if we accept $H_{0}$ hypothesis, it shows that there is not a casual correlation between the budget balance and energy imports. Hence, it is obtained that a relationship between these parameters is not a matter of fact in those countries within those years.

\section{CONCLUSION}

Mostly in the countries dependent on the energy supplied by the other countries, there has been a positive correlation between the energy imports and the current account deficit. To be more specific, growing energy demand of developing countries has resulted in depletion of energy resources and increase in energy imports so that there occurs current account deficits. The primary reason for not considering a direct association between energy demand and the budget deficit is that many developing countries choose the privatization as a solution instead of establishing public investments Need to emphasize that, the resultant of energy imports is directly seen in the account deficit more than in the budget deficit; but, the effect of the energy imports upon general equilibrium of economy might result in the budget deficits.

In this study, the relationship between budget deficit and energy imports is intended to get explored for some European countries (Germany, France, Italy, Spain) and Turkey. Panel ARDL cointegration test is applied due to separate correlations of the unit root test parameters in accordance with the improved econometric estimations. With the application of the test, it is estimated that there is not a cointegrated relation between the parameters. This estimation is supported by Hausman causality test, as well. Pairwise Dumitrescu Hurlin Panel causality test also confirms the non-causality of the relationship between the parameters. All these data corresponds to the estimations of the economic theory, and it is mainly caused by the absence of energy imports as a parameter inside the performance budgets of the central administration. The causal relationship is mostly manifested in terms of balance of current accounts. This result may change for the net energy exporter countries, but it is another matter to research.

Considering the results of econometric estimations, it is expected that the countries with shortage of energy resources are mostly prone to get dependent on the energy supplied by other countries, and following, a budget deficit emerges out of that dependency.

\section{REFERENCES}

[1] World Energy Council, World Energy Resources: 2013 Survey, London, 2013.

[2] US Energy Information Administration. (2013). International energy statistics. [Online]. Available: http://www.eia.gov/cfapps/ipdbproject/IEDIndex3.cfm

[3] Federal Ministry for the Environment. Nature Conservation and Nuclear Safety (BMU). Renewable energies. [Online]. Available: http://www.bmub.bund.de/fileadmin/Daten_BMU/Pools/Broschueren/ Motor_der_Energiewende_eng_bf.pdf

[4] The Encyclopedia of Earth, Energy Profile of France. [Online] Available: http://www.eoearth.org/view/article/152496/

[5] European Commission. (2014). Energy Economic Developments in Europe. [Online]. Available: http://ec.europa.eu/economy_finance/publications/european_economy /2014/energy-economic-developments-in-europe_en.htm

[6] Ministry of Industry, Tourism and Trade. Spain's National Renewable Energy Action Plan 2011-2020. [Online]. Available: http://ec.europa.eu/energy/renewables/action_plan_en.htm

[7] Open EI. Spain: Energy Resources. [Online]. Available: http://en.openei.org/wiki/Spain

[8] Ministero dello Sviluppo Economico. (March 2013). Italy's National Energy Strategy: For a more competitive and sustainable energy. [Online]. Available: http://www.encharter.org/fileadmin/user_upload/Energy_policies_and _legislation/Italy_2013_National_Energy_Strategy_ENG.pdf

[9] M. M. ve D. Uysal, "Türkiye ekonomisinde enerji tüketimi ve ekonomik büyüme," Maliye Dergisi, vol. 157, pp. 105-115, 2009. 
[10] T. C. E. ve T. K. Bakanlığı. Dünyada ve Türkiye'de enerji görünümü. [Online]. Available: http://www.enerji.gov.tr/index.php

[11] M. Toman and B. Jemelkova, "Energy and economic development: An assessment of the state of knowledge," in Proc. Rural Energy Transitions Conference, The Energy and Resources Institute in New Delhi, India, 2002, pp. 1-25.

[12] V. Ulusoy, "Ekonomik büyüme ve enerji tüketimi: Bir ekonometrik uygulama," I. Ulusal Türkiye'de Enerji ve Kalkinma Sempozyumu, İstanbul, 2006.

[13] BP Statistical Review of World Energy. (June 2011). [Online]. Available: http://www.bp.com/

[14] Türkiye Cumhuriyet Merkez Bankası. Ödemeler dengesi istatistikleri'ne ilişkin yöntemsel açiklama. [Online]. Available: http://www.tcmb.gov.tr/odemedenge/odemet.pdf

[15] M. Demir, "Enerji ithalati cari açik ilişkisi, Var analizi ile Türkiye üzerine bir inceleme," Akademik Araştırmalar ve Çalışmalar Dergisi, vol. 5, no. 9, pp. 20-46, 2013.

[16] The World Bank. [Online]. Available: http://www.worldbank.org/

[17] İ. Göçer, M. Mercan, and M. M. Dam, "Budget deficits sustainability of selected eu countries and turkey: Panel cointegration analysis," in Proc 3rd International Symposium on Sustainable Development, Sarajevo, 2012, pp. 238-249.

[18] E. S. H. Yu and J. Y. Choi, "The causal relationship between energy and GDP: An international comparison," Journal of Energy and Development, vol. 10, pp. 249-272, 1985.

[19] E. C. Prescoft, "American economic association," The American Economic Review, vol. 92, no. 2, pp. 1-15, May 2002.

[20] Ö. K. ve A. Develi, Türkiye'de Birincil Enerji Kullanimi, Üretimi ve Gayri Safi Yurt İçi Hasıla (GSYİH) Arasindaki Ilişski, Dokuz Eylül Üniversitesi İktisadi ve İdari Bilimler Fakültesi Dergisi, vol. 27, no. 2, pp. 1-25, 2012.

[21] R. Y. ve G. Kerimoğlu, "Türkiye'de enerji tüketimi, ekonomik büyüme ve cari açik ilişkisi," Ekonomi Bilimleri Dergisi, vol. 3, no. 2, pp. 191-201, 2011.

[22] M. A. Bilginoğlu and C. Dumrul, "A co-integration analysis on the energy dependency of the Turkish," Journal of Yasar University, vol. 26, no. 7, pp. 4392-4414, 2012.

[23] S. B. ve F. Kesikoğlu, Türkiye'de Bütçe Açıklarının Temel Makroekonomik Değişkenler Üzerine Etkisi (1987-2003 Var, Etki-Tepki Analizi, Varyans Ayrıştırması), Ankara Üniversitesi Sosyal Bilimler Fakültesi Dergisi, pp. 60-84, 2003.

[24] B. H. Baltagi, Econometric Analysis of Panel Data, Third Edition, John Wiley\&Sons Ltd., England, 2005.
[25] A. R. Sandalcılar, BRIC ülkelerinde ekonomik büyüme ve ihracat arasindaki ilişki: Panel eşbütünleşme ve panel nedensellik, Süleyman Demirel Üniversitesi İIBB Dergisi, vol. 17, no. 1, pp. 161-179, 2012.

[26] S. Çınar, Gelir ve $\mathrm{CO}_{2}$ Emisyonu İlişkisi: Panel Birim Kök ve Eşbütünleşme Testi, Uludağ Üniversitesi İ̈BF Dergisi, vol. 30, no. 2, pp. 71-83, 2011.

[27] S. Çınar, OECD Ülkelerinde kişi başina GSYIHH Durağan mi? Panel veri Analizi, Marmara Üniversitesi İ̈BF Dergisi, vol. 29, no. 2, pp. 591-601, 2010.

[28] E. F. Blackburne III and M. W. Frank, "Estimation of nonstationary heterogeneous panels," The Stata Journal, Sam Houston State University, 2007.

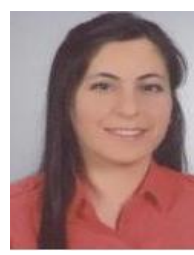

Zerife Yıldırım was born in Bozova, Şanlıurfa, Turkey in 1981.

She received her bachelor's degree and master's degree in economics from University of Şanlıurfa. She has been working as a research assistant in 9 Eylü University (İzmir) since 2010. She is going on her academic career with a $\mathrm{PhD}$ program at the same university as well.

She finished her MA thesis named 'Economic effects of capital flows in developing countries: Turkey instance' under the guidance of Dr. Erşan Sever in Harran University, Şanlıurfa, Turkey in June 2008.

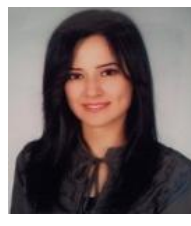

Ayşe Atılgan Yaşa was born in Akhisar, Manisa, Turkey in 1988.

She received her bachleor's degree in finance from Balıkesir University. She was awarded an MA in finance by 9 Eylül University, İzmir. She has been working as a research assistant in 9 Eylül University since 2010, and she is going on her academic career with a $\mathrm{PhD}$ program at the same university, as well.

The studies of Atılgan Yaşa include: Kâmil Tüğen and Ayşe Atilgan Yaşa, "Considérations sur les changements intervenus dans les gestions financières des Municipalités durant le processus d'adhésion de la Turquie à l'Union Européenne," Przeglad Prawa i Administracji, vol. 94, pp. 41-53, 2013; An analysis on the adjustments of the financial management of municipalities associated with the accession process of Turkey towards European Union, MA thesis; The tax policies of turkey and the world applied after economic crisis of 2007, BA thesis project. 